\title{
石炭灰の前処理が水熱処理ケイ酸カルシウム硬化体の 強度に及ぼす影響十
}

\author{
$\begin{array}{lllll}\text { 芦 } \text { 田 利 } \text { 文 }^{*} \text { 中 林 一 朗** } \\ \text { 岡 本 照 彦** } & \text { 平 島 } \text { 康 }^{* * *}\end{array}$ \\ Properties of Calcium Silicate Briquette \\ Improved by Pretreatment of Raw Materials of Coal Ash
}

by

\author{
Toshifumi Ashida*, Ichiro Nakabayashi**, Teruhiko Oкамото*** \\ and Yasushi HiRASHIMA $* * *$
}

\begin{abstract}
Calcium silicate briquettes were hydrothermally made from the raw materials of waste coal ash which were activated by pretreating with $0.05 \mathrm{~mol} / l-\mathrm{HCl}$ solution or $0.1 \mathrm{~mol} / l-\mathrm{NaOH}$ solution at $80^{\circ} \mathrm{C}$ for 4 hours. After curing for 72 hours, the briquette consisted of hydrogarnet, $\mathrm{C}-\mathrm{S}-\mathrm{H}$, and tobermorite. The briquette made from the pretreated coal ash had lower bending strength and lower bulk density than those made from untreated coal ash. To improve the strength, waste silica containing $85 \mathrm{wt} \% \alpha$-quartz was added with the pretreated coal ash. The pretreatment of coal ash indirectly improved the reactivity of waste silica, since hydrothermal solution easily invaded into the briquette through pore developed by the reaction of coal ash. The briquettes having bending strength of $18.7 \mathrm{MPa}$ and bulk density of $1.42 \mathrm{Mg} / \mathrm{m}^{3}$ were obtained.
\end{abstract}

Key words : Calcium silicate briquette, Pretreated coal ash, Hydrothermal treatment

\section{1 緒 言}

現在日本国内に扔いて，毎年数百万トンの石炭灰が石 炭ボイラーから発生している。石炭灰の主成分は $\mathrm{SiO}_{2}$, $\mathrm{Al}_{2} \mathrm{O}_{3}$ などであるため, $\mathrm{SiO}_{2}$ 成分比が高く強熱減量値 (Ig. Loss) が低い石炭灰は, “フライアッシュ”として セメント工業等に有効利用されている. 一方, 低品位の 約 $60 \%$ の石炭灭は, 資源としては有効利用されること なく, 海面埋立, 陸上埋立と称して投棄されている. し かしながら; 近年発生する石炭灰の増加, 粉塵公害など の問題から投棄場所の確保が困難となり, 低品位の石炭 灰を資源として有効再利用することが望まれている.

私たちは，未燃焼カーボンを多量に含む Ig. Loss の 大きな石炭灰を用いても, 適当な石英質原料の添加, な らびに水熱処理を施すことによって，十分な強度を有す るケイ酸カルシウム硬化体が作製できることを報告した。 この場合硬化体は, 石英とハイドロガーネット, 非晶質 ケイ酸カルシウム水和物 $(\mathrm{C}-\mathrm{S}-\mathrm{H})$ を主成分とし, 結晶 性のケイ酸カルシウム水和物であるトバモライトなどは ほとんど見られなかった．硬化体の強度が石英質原料の 添加により向上したのは, 石英粒子表面に生成した C -S-Hによって結合した未反応石英が，骨材として機能 したためと推測された。
硬化体中の石炭灰の反応性が低い原因として，石炭灰 中のガラス粒子の表面を硬石膏 (無水硫酸カルシウム), 炭酸カルシウム, カルシウム成分に富むガラス相などが 覆い, ガラスの溶出が妨げられること，これらの相は $\mathrm{HCl}$ 溶液あるいは $\mathrm{NaOH}$ 溶液により除去できることが 報告されている. この研究では, 石炭灰の反応性を向上 させることを目的として, $\mathrm{HCl}$ 溶液あるいは $\mathrm{NaOH}$ 溶 液でそれぞれ前処理した石炭灰を原料に用い硬化体を作 製した。得られた硬化体は, 粉末 $\mathrm{X}$ 線回折法により生 成相の同定を行った。また，曲げ強度，かさ密度などの 特性について評価した。

\section{2 実，験 方 法}

本実験で用いた石炭灰は，既報と同じく鳴門塩業(侏微 粉炭流動床ボイラーから産したものである．この石炭灰 の化学組成を Table I (a) に示す. 表中の Ig. Loss の大 半は, CHN 分析の結果から未燃焼カーボンであった。 表中にみられるように石炭灰の主成分は $\mathrm{SiO}_{2}$ と $\mathrm{Al}_{2} \mathrm{O}_{3}$ であり, 水熱反応に関与しない未燃焼カーボンを除いて 考えると, $\mathrm{SiO}_{2}$ と $\mathrm{Al}_{2} \mathrm{O}_{3}$ の含量は $70 \mathrm{wt} \%$ 以上となる。 これらの成分は粉末 $\mathrm{X}$ 線回折から観測される結晶相が 少ないことから, 大半はガラス相として石炭灰中に存在 しているものと考えた.

\section{$\dagger \quad$ 原稿受理 平成 7 年 7 月11日 Received July 11, 1995}

* 正会員 近畿大学工学部工業化学科 ₹739-21 東広島市高屋うめの辺, Dept. of Indust. Chem., Kinki Univ., Umenobe, Higashihiroshima, 739-21

** 正会 員 徳島大学工学部化学応用工学科 $\overline{7} 770$ 徳島市南常三島町, Dept. Chem. Sci. and Tech., Tokushima Univ., Minami-Josanjima -cho, Tokushima, 770

鳴門塩業(株) T772 鳴門市撫養町黑崎字松島, Naruto Salt Mfg. Co. Ltd., Muya-cho, Naruto, 772

**** 正会員 徳島県工業技術センター 7770 徳島市雑貨町西開, Tokushima Pref. Indust. Tech. Center, Saika-cho, Tokushima, 770 
Table I. Chemical compositions of raw materials. (a) Chemical compositions of coal ash/wt\%.

\begin{tabular}{c|c|c|c|c|c|c|c}
\hline $\mathrm{SiO}_{2}$ & $\mathrm{Al}_{2} \mathrm{O}_{3}$ & $\mathrm{CaO}$ & $\mathrm{Fe}_{2} \mathrm{O}_{3}$ & $\mathrm{Na}_{2} \mathrm{O}$ & $\mathrm{MgO}$ & $\mathrm{K}_{2} \mathrm{O}$ & Ig. Loss \\
\hline 35.9 & 23.8 & 8.0 & 7.4 & 1.7 & 1.6 & 1.7 & 19.9 \\
\hline
\end{tabular}

(b) Chemical compositions of waste silica/wt\%.

\begin{tabular}{c|c|c|c|c|c|c|c}
\hline $\mathrm{SiO}_{2}$ & $\mathrm{Al}_{2} \mathrm{O}_{3}$ & $\mathrm{Fe}_{2} \mathrm{O}_{3}$ & $\mathrm{~K}_{2} \mathrm{O}$ & $\mathrm{TiO}_{2}$ & $\mathrm{CaO}$ & $\mathrm{MgO}$ & Ig. Loss \\
\hline 85.5 & 6.2 & 3.6 & 1.2 & 0.7 & 0.3 & 0.3 & 2.5 \\
\hline
\end{tabular}

硬化体特性の改善のためケイ石廃泥を添加した．ケイ 石廃泥は徳島県勝浦川流域の砕石場から産したもので, その特性值は既報と同様, 平均粒子径 $5.6 \mu \mathrm{m}$ の石英粒 子を約 $85 \mathrm{wt} \%$ 含有する. ケイ石廃泥の化学分析值を Table I (b) に示す.

石炭灰の前処理には $0.05 \mathrm{~mol} / l$ の $\mathrm{HCl}$ 溶液あるいは $0.1 \mathrm{~mol} / l$ の $\mathrm{NaOH}$ 溶液を用いた. 石炭灰を 10 倍量の 溶液中で, $80^{\circ} \mathrm{C} \cdot 4$ 時間加熱し前処理とした，それぞ れの前処理した石炭灰をろ過後, カルシウム成分が炭酸 化されることを防ぐため真空乾燥し硬化体原料に供した. 前処理後の石炭灰の粉末 $\mathrm{X}$ 線回折図を比較すると, $\mathrm{HCl}$ 処理のものでは硬石膏の主ピークが原料に比べて $10 \%$ 弱くなったが, その他のピークには変化はなかっ た. $\mathrm{NaOH}$ 前処理した場合は, 硬石高および石英の回 折線に変化は認められなかった。 それぞれの前処理前後 の石炭灰の比表面積値, ならびに石炭灰粒子の SEM 観 察結果からも, 石炭灰粒子の形状に变化は認められな かった。

さらにろ液中の溶脱成分を ICP 発光分析により分析 した. $\mathrm{HCl}$ 処理では $\mathrm{Ca}$ の溶脱量が最も高く石炭灰 $1 \mathrm{~g}$ に対して $\mathrm{CaO}$ として $11 \mathrm{mg}$ 検出されたが, $\mathrm{Si}, \mathrm{Al}$ な どは $0.2 \mathrm{mg}$ 以下であった. $\mathrm{NaOH}$ 処理では $\mathrm{Al}$ の溶脱 量が最も高く, $\mathrm{Al}_{2} \mathrm{O}_{3}$ として $2 \mathrm{mg}$ 検出されたが, 他成 分は $0.2 \mathrm{mg}$ 以下であった. 恒松らも種々の石炭灰に同 様な処理を行い, 今回と同程度の $\mathrm{Al}, \mathrm{Si}$ の溶脱を報告 している. $\mathrm{HCl}$ 処理, $\mathrm{NaOH}$ 処理それぞれの処理に よって溶脱する成分は異なるが, 溶脱量は硬化体原料全 体に対しては微量であると判断し, 硬化体原料として混 合する水酸化カルシウムおよび特性改善のため添加する ケイ石廃泥の石炭灰に対する分量は, 石炭灰の前処理前 の化学分析值 (Table I) から算出した值を用いた.

前処理後の石炭灰と試薬水酸化カルシウムとをカルシ ウムとシリカの物質量の比 (モル) として, $\mathrm{Ca} / \mathrm{Si}$ $=1.0$ を中心に所定の比率で混合し硬化体原料とした. ケイ石廃泥を添加する場合には，この段階で硬化体原料 中の全 Si 成分に対して 0.25 となるように添加し, それ に応じて $\mathrm{Ca} / \mathrm{Si}$ 比が所定の比率になるように水酸化力 ルシウムを添加した.

硬化体の供試原料に $11 \mathrm{wt} \%$ の水をバインダーとし て添加し, 油圧プレスを用い $34 \mathrm{MPa}$ の圧力で $10 \times 7$ $\times 100 \mathrm{~mm}$ の直方体に成形した. 水熱処理溶媒には水を 用い, $\mathrm{NaOH}$ などのアルカリの添加は行わなかった. 成形体を内容積 $1000 \mathrm{~m} l$ のテフロン製の内容器のオー トクレイブを用いて, $180^{\circ} \mathrm{C}$, 飽和水蒸気圧 $1 \mathrm{MPa}$ で

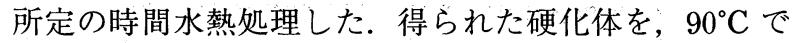
12 時間乾燥し, 粉末 $\mathrm{X}$ 線回折法によって構成物質を同 定した，硬化体の特性値は，3点曲げ試験による曲げ強 度，JIS R2205に基づく気孔率，吸水率，かさ密度の測 定により評価した。

\section{3 結果と考 察}

\section{$3 \cdot 1$ ケイ石廃泥無添加の硬化体}

Fig. 1 に HCl 処理した石炭灰を用いた硬化体の，Fig. 2 に NaOH 処理した石炭灰を用いた硬化体の処理時間 による粉末 X 線回折図の変化を示す. どちらの試料に おいても水酸化カルシウムは, 水熱処理 4 時間でほぼ消 失しており，ハイドロガーネット，あるいは $\mathrm{C}-\mathrm{S}-\mathrm{H}$ の 生成に用いられたと考えられる。また硬石膏は反応初期 からほぼ恒量であり，水熱処理においてエトリンガイト などの, 硬石膏を原料とした相は生成していなかった.

ハイドロガーネットは，水熱処理 1 時間後から確認さ れた. 生成したハイドロガーネットは $2 \theta=17.7^{\circ}$ のピー クから判断すると，既報の硬化体中に生成したものより， 結晶性が良好であった。. 以上のことから, 石炭灰のハイ ドロガーネットへの反応性は極めて高いと考えられる.

ケイ酸カルシウム水和物についてはどちらの前処理に ついても, 18 時間以後に $2 \theta=30 \sim 31^{\circ}$ 付近に幅の広い ピークが確認され， C-S-H が生成していることがわ かった. C-S-H は水酸化カルシウムが消失した 4 時間 後の時点で生成していたと考えられるが，結晶性が低 かったため粉末 $\mathrm{X}$ 線回折では確認されなかったものと 推察される.さらにトバモライトに特徵的な $7.8^{\circ}$ のピ 一クの強度は, $\mathrm{NaOH}$ 処理の方が $\mathrm{HCl}$ 処理の試料より も 36 時間以後増加した. したがって $\mathrm{NaOH}$ 処理の方が $\mathrm{HCl}$ 処理に比べ, 石炭灰のケイ酸カルシウム水和物へ の反応性は高いと判断した.

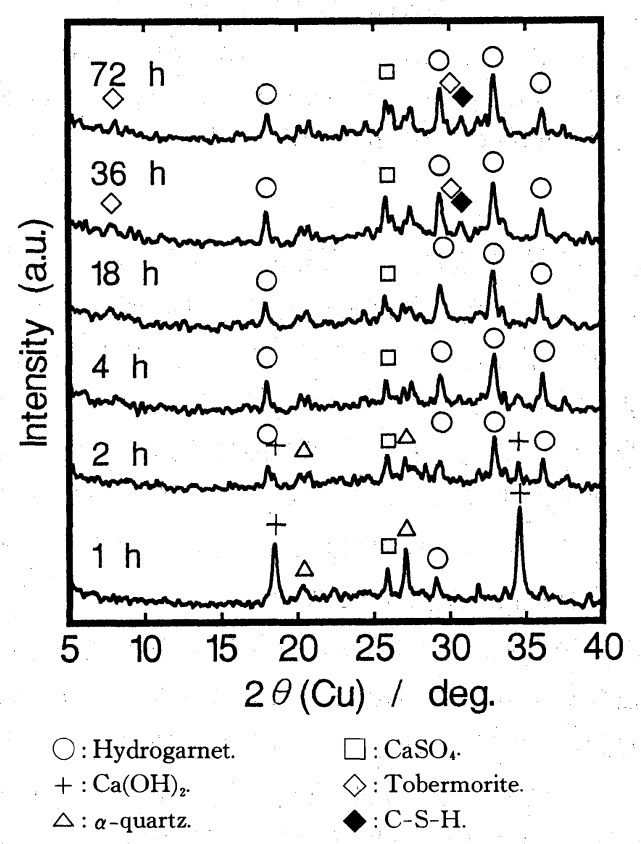

Fig. 1. XRD patterns of the briquettes made from pretreated coal ash with $\mathrm{HCl}$ solution. Briquettes were cured from 1 to $72 \mathrm{~h}$. 


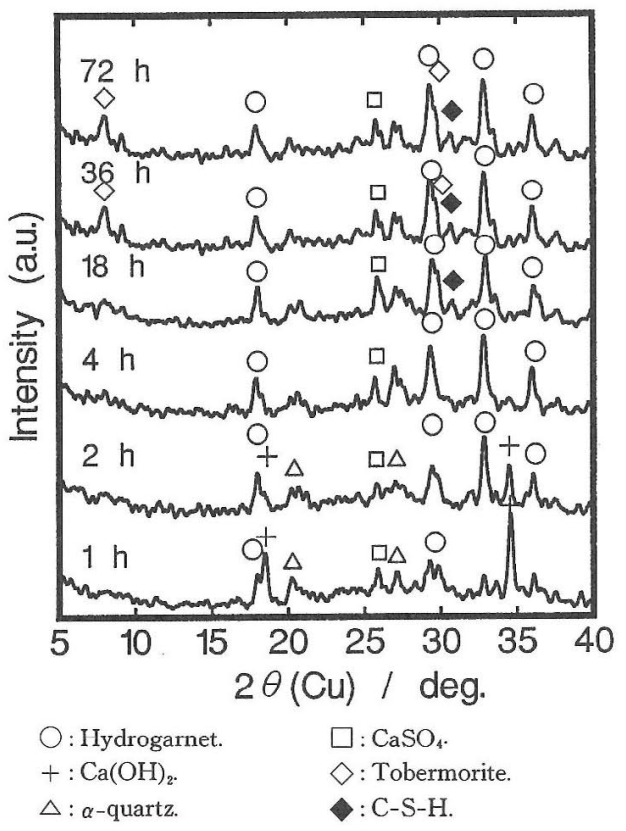

Fig. 2. XRD patterns of the briquettes made from preteated coal ash with $\mathrm{NaOH}$ solution. Briquettes were cured from 1 to $72 \mathrm{~h}$.

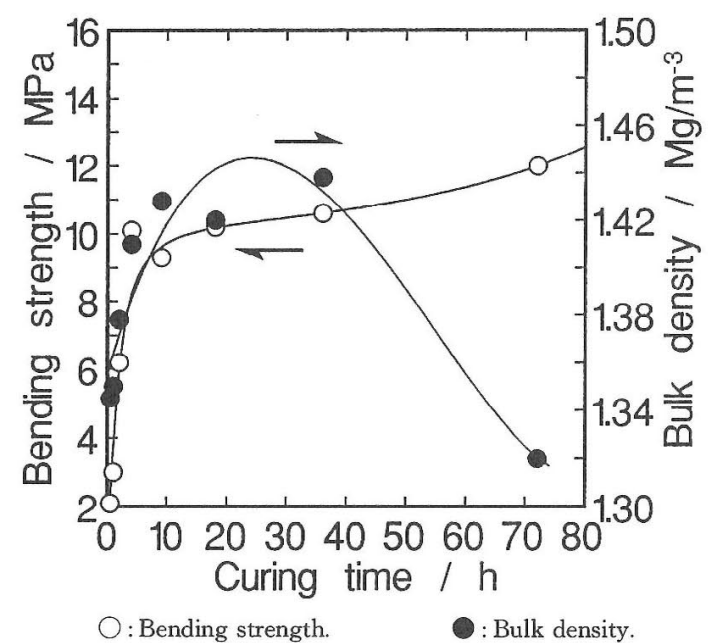

Fig. 3. Change of properties of the briquettes made from pretreated coal ash with IICl solution.

Fig. 3 に $\mathrm{HCl}$ 処理した石炭灰から作製した硬化体の 特性值（かさ密度，曲げ強度）の処理時間による变化を 示す. かさ密度は 30 - 40 時間までは, 処理時間に応じ て増加しているが，それ以上では低下した。このか密 度の低下は，気孔率と吸水率の増加に対応していること から，処理時間 72 時間では硬化体に多くの空孔が発生 したと考えられる。曲げ強度は水熱処理初期に急激に増 加し， それ以降は緩やかに増加した。Fig. 1 の粉末 X 線 回折の結果から，反応初期に硬化体の徵密化が進行し硬 化体強度が上昇した領域は，ハイドロガーネットの生成 する期間に対応しており，水熱処理初期にはハイドロガ ーネットの生成とともに緻密化が進行することが分かっ た。一方，かさ密度が低下する 30 時間以上の領域では， ハイドロガーネットの生成が終了し, 結晶性の低い $\mathrm{C}$ $-\mathrm{S}-\mathrm{H}$ からトバモライトの生成する期間に対応すること

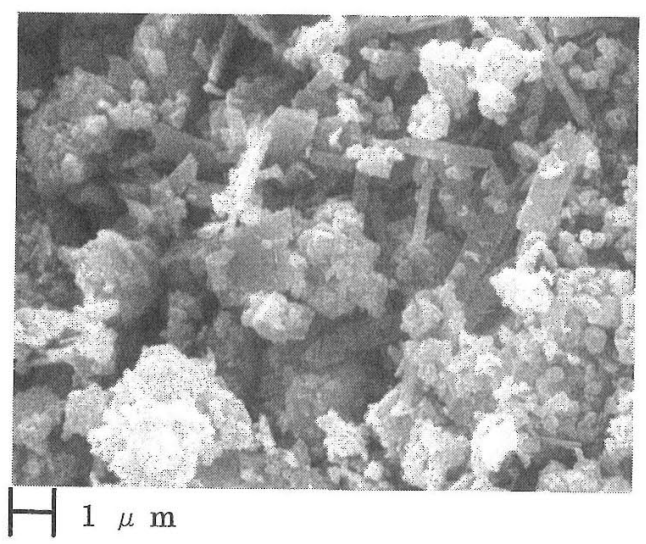

Fig. 4. SEM micrograph showing the fracture surface of the briquette made from pretreated coal ash with $\mathrm{HCl}$ solution, after curing for $72 \mathrm{~h}$.

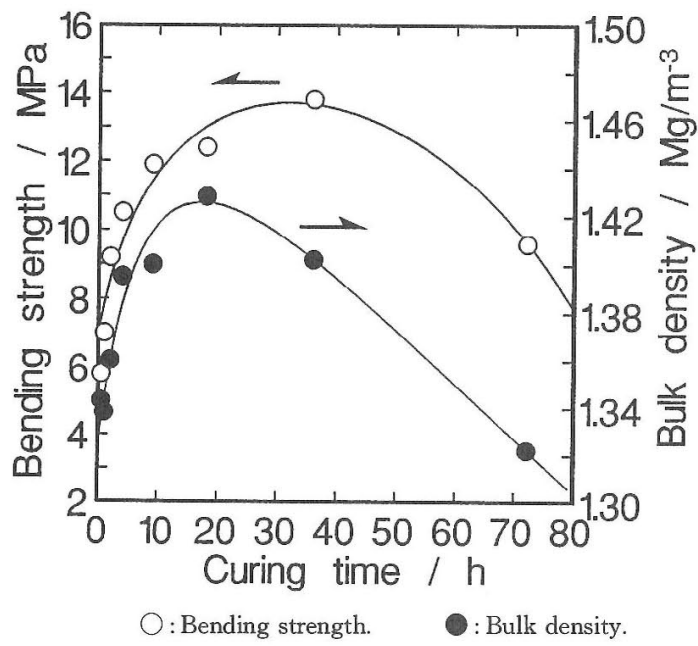

Fig. 5. Change of properties of the briquettes made from pretreated coal ash with $\mathrm{NaOH}$ solution.

が分かった. Fig. 4 に HCl 処理した試料の水熱処理 72 時間後の破断面の SEM 写真を示す。ハイドロガーネッ トおよび C-S-H ゲルの組織の中に数 $\mu \mathrm{m}$ の針状のトバ モライトあるいは C-S-H が観察された。

Fig. 5 に NaOH 処理した石炭灰から作製した硬化体 の特性值の処理時間による変化を示す. $\mathrm{HCl}$ 処理した 硬化体と比較すると, か子密度は，20 時間までに最大 值を示し, それ以後は $\mathrm{HCl}$ 処理による硬化体と同様に 低下した。曲げ強度は $\mathrm{HCl}$ 処理と同じく水熱反応初期 に急激に増加し, 36 時間で最大值 $13.9 \mathrm{MPa}$ を示した が, 反応時間が長くなると大きく低下した，水熱反応初 期のかさ密度の上昇, 曲げ強度の増加は $\mathrm{HCl}$ 処理と同 じくハイドロガーネットの生成によるものである。

Fig. 6 に水熱処理 72 時間の硬化体の破断面の SEM 写真を示す。破断面には大きな空孔が見られその周辺に は針状あるいはりん片状の発達したトバモライト，C -S-H が見られた。また部分的にFig. 6 (b)の様にこれら のトバモライトが集合している部分も観察された。 Fig. 2 の粉末 X 線回折図から硬化体中にはトバモライトが 多く含まれているが，大半はこのように集合して生成し ていると考えられる。長時間の水熱処理によりトバモラ 

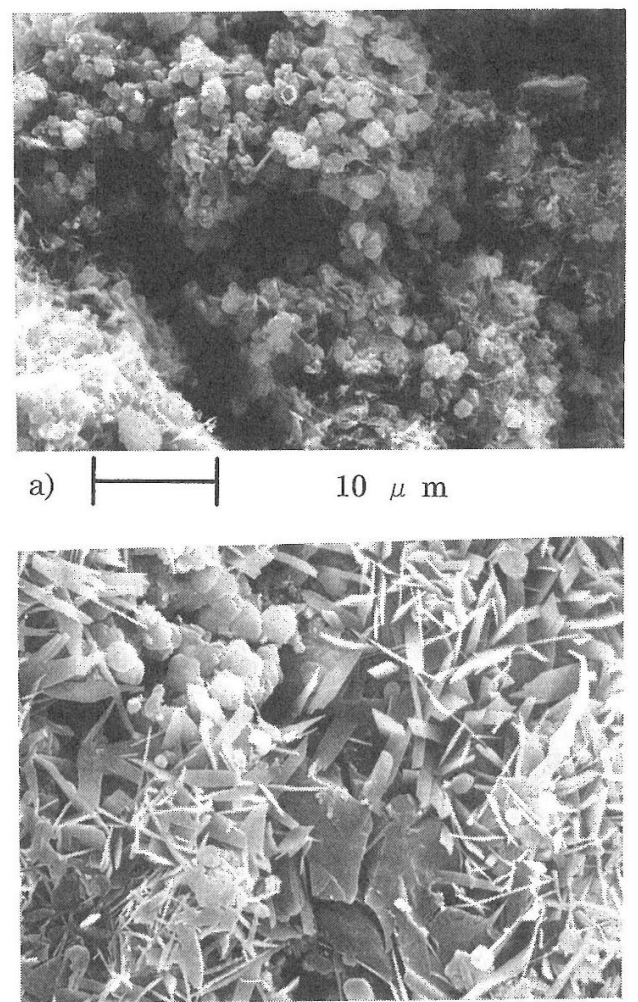

b)

$10 \mu \mathrm{m}$

Fig. 6. SEM micrograph showing the fracture surface of the briquette made from pretreated coal ash with $\mathrm{NaOH}$ solution, after curing for $72 \mathrm{~h}$.

イトが生成したにもかかわらず強度が低トした原因は， 硬化体の一部分に生成したトバモライトは強度の向上に は寄与できず，逆に生成に伴い発生した大きな空孔が破 壞の起点となったた好推定される。

以上の上うに前処理によって石炭灰の反応性が向上し, 水熱処理 72 時間では硬化体内部にハイドロガーネット に加えトバモライトが生成することが明らかとなった。 そこで以下のケイ石廃泥を添加した場合にも, 水熱処理 時間は 72 時問とした。

\section{$3 \cdot 2$ ケイ石廃泥を添加した硬化体}

Fig. 7 にケイ石廃泥を添加した場合の硬化体の粉末 X 線回折図を示す。どの試料についても，ハイドロガー ネット拉よびトバモライトが生成していた，未反応石英 も残存しているが, 石英の $26.6^{\circ}(2 \theta)$ の回折線強度より 最も多く残存している $\mathrm{Ca} / \mathrm{Si}=0.7$ の場合 (Fig. 7 (b)), 添加量の約 $60 \%$ の残存量であり，既報で報告した前処 理をしない場合に比較して未反応石英量は隇少していた。 ここで定量には $4 \mathrm{wt} \%$ の Si を内部標準として添加し， それぞれの硬化体原料中の石英の回折強度との比から概 算した. $\mathrm{Ca} / \mathrm{Si}$ 比を上げると, 未反応石英のピーク強 度は隇少し, $\mathrm{Ca} / \mathrm{Si}=1.2$ では添加量の約 $20 \%$ の残存 量となった (Fig. 7 (d))。 また石英の減少に対応してト バモライトのピーク強度が増加し，ハイドロガーネット はほとんど恋化がないことから，反応した石英は主にト バモライトや C-S-H な゙のケイ酸カルシウム水和物を 生成したと考えられる. $\mathrm{NaOH}$ 処理した場合, 同じ $\mathrm{Ca}$

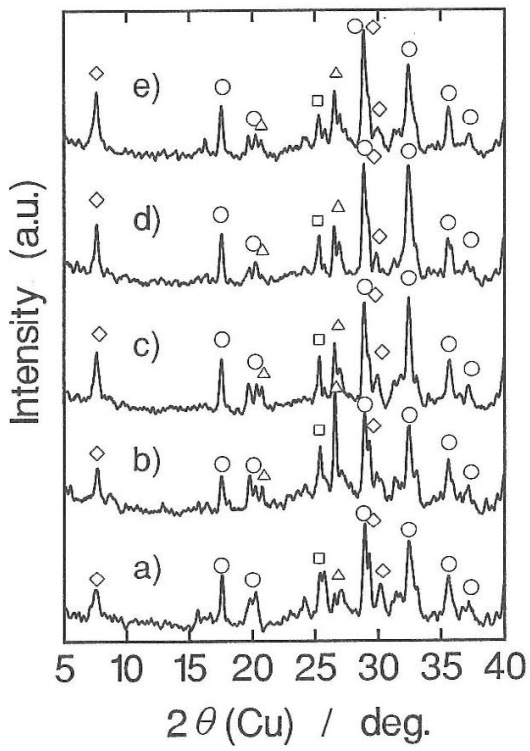

(a) $\mathrm{Ca} / \mathrm{Si}=1.0, \mathrm{HCl}$ pretreatment, no waste silica.

(b) $\mathrm{Ca} / \mathrm{Si}=0.7, \mathrm{HCl}$ pretreatment, 0.25 waste silica.

(c) $\mathrm{Ca} / \mathrm{Si}=1.0, \mathrm{HCl}$ pretreatment, 0.25 waste silica.

(d) $\mathrm{Ca} / \mathrm{Si}=1.2, \mathrm{HCl}$ pretreatment, 0.25 waste silica.

(e) $\mathrm{Ca} / \mathrm{Si}=1.0, \mathrm{NaOH}$ pretreatment, 0.25 waste silica.

$\mathrm{O}:$ Hydrogarnet. $\quad \Delta: \alpha$-quartz.

$\square: \mathrm{CaSO}_{4}$. $\diamond:$ Tobermorite.

Fig. 7. XRD patterns of the briquettes made from pretreated coal ash.

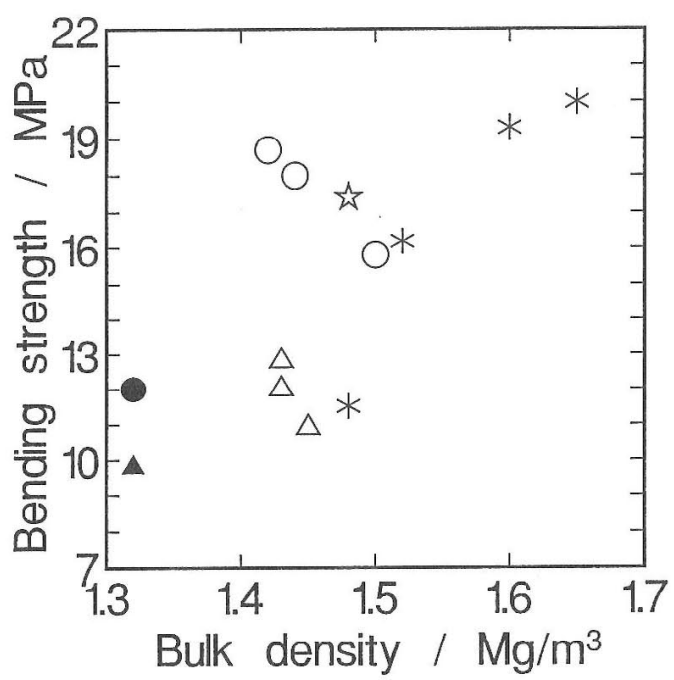

\footnotetext{
: $\mathrm{HCl}$ pretreatment, no waste silica.

A : $\mathrm{NaOH}$ pretreatment, no waste silica.

$\mathrm{O}: \mathrm{HCl}$ pretreatment, 0.25 waste silica.

$\triangle: \mathrm{NaOH}$ pretreatment, 0.25 waste silica.

* : Without pretreatment, additive of waste silica. 综: Made from carbon free coal ash.
}

Fig. 8. Properties of the briquettes (bulk density ws. bending strength).

/ $\mathrm{Si}$ 比の $\mathrm{HCl}$ 処理した試料と比較すると, 残存する石 英は, $\mathrm{HCl}$ 処理した試料より減少していた。

カルシウム成分の比率が上がるとともに残存石英量が 低下したことから，ケイ石廃泥の硬化体内の反応性は良 好であると判断される. $\mathrm{HCl}$ 処理と $\mathrm{NaOH}$ 处理のどち らの前処理によっても石炭炏たけでなく, 添加したケイ 
Table II. Physical properties of the briquettes.

\begin{tabular}{c|c|l|c|c|c|c|c|c}
\hline No. & $\begin{array}{c}\mathrm{Ca} / \mathrm{Si} \\
\text { ratio }\end{array}$ & $\begin{array}{c}\text { Waste } \\
\text { silica }\end{array}$ & $\begin{array}{c}\text { Solution for } \\
\text { autoclave }\end{array}$ & Pretreatment & $\begin{array}{c}\text { Bending } \\
\text { strength/MPa }\end{array}$ & $\begin{array}{c}\text { Bulk density } \\
/ \mathrm{Mg} / \mathrm{m}^{3}\end{array}$ & Porosity/\% & $\begin{array}{c}\text { Water } \\
\text { absorption/\% }\end{array}$ \\
\hline a & 1.0 & 0 & $\mathrm{H}_{2} \mathrm{O}$ & no & 11.1 & 1.42 & 4.2 & 31.7 \\
b & 1.0 & 0 & $\mathrm{NaOH}$ & no & 11.5 & 1.47 & 39.7 & 27.2 \\
$*_{c}$ & 1.0 & 0 & $\mathrm{H}_{2} \mathrm{O}$ & no & 17.4 & 1.48 & 43.0 & 28.2 \\
d & 1.0 & 0.25 & $\mathrm{H}_{2} \mathrm{O}$ & no & 14.8 & 1.52 & 41.6 & 27.8 \\
e & 1.0 & 0.25 & $\mathrm{NaOH}$ & no & 19.5 & 1.60 & 35.3 & 22.0 \\
$\mathrm{f}$ & 1.0 & 0 & $\mathrm{H}_{2} \mathrm{O}$ & $\mathrm{HCl}$ & 12.0 & 1.32 & 45.9 & 33.9 \\
g & 1.0 & 0 & $\mathrm{H}_{2} \mathrm{O}$ & $\mathrm{NaOH}$ & 9.8 & 1.32 & 44.7 & 32.7 \\
h & 0.7 & 0.25 & $\mathrm{H}_{2} \mathrm{O}$ & $\mathrm{HCl}$ & 18.0 & 1.44 & 41.9 & 29.1 \\
i & 1.0 & 0.25 & $\mathrm{H}_{2} \mathrm{O}$ & $\mathrm{HCl}$ & 18.7 & 1.42 & 43.4 & 30.5 \\
j & 1.2 & 0.25 & $\mathrm{H}_{2} \mathrm{O}$ & $\mathrm{HCl}$ & 15.8 & 1.50 & 41.5 & 27.5 \\
k & 1.0 & 0.25 & $\mathrm{H}_{2} \mathrm{O}$ & $\mathrm{NaOH}$ & 10.9 & 1.45 & 42.3 & 29.0 \\
\hline
\end{tabular}

* Unburned carbon was removed by heating at $550^{\circ} \mathrm{C}$ for $12 \mathrm{~h}$.

石廃泥の反応性も向上した原因を以下の様に考えた。水 熱反応初期に石炭灰々水酸化カルシウムからハイドロガ 一ネットが生成し，硬化体内部に空隙が生じる。生じた 空隙を通じて，残存するカルシウム成分に富む溶媒が， 硬化体内部に侵入し石英を溶出させる。溶出したシリカ 成分がカルシウム成分と反応し C-S-H とトバモライト が生成する。つまり，石英一カルシウム系の反応律速で ある石英の溶出が，硬化体に発生した空隙によって容易 となり，結果的にケイ石廃泥の反応性が向上する効果が 現れたと考えられる。

Table II に主要な硬化体の特性值を，Fig. 8 にかさ密 度と曲げ强度で表した硬化体の特性值を，前处理をしな い石炭灰を用いて作製した硬化体の特性值を含めて示す。 また，未燃焼カーボンを取り除いた石炭灰を用いて作製 した硬化体の特性値も合わせて示した (Table II (c), Fig. 8)。な押未燃焼カーボンは不炭灰を $550^{\circ} \mathrm{C}$ で 12 時 間焼成し取り除いた。未燃焼カーボンを取り除いた石岸 灰からなる硬化体は，曲げ強度 $17.4 \mathrm{MPa}$ ，かさ密度 $1.48 \mathrm{Mg} / \mathrm{m}^{3}$ を示し (Table II (c))，同様な処理をした未 燃焼カーボンを含有する硬化体と比べると（Table II (a))，未燃焼カーボンが破壞の起点となり強度を低下さ せていることが分かる．ケイ石廃泥の添加によって強度 は向上するが，前処理をしない場合かさ密度の上昇も大

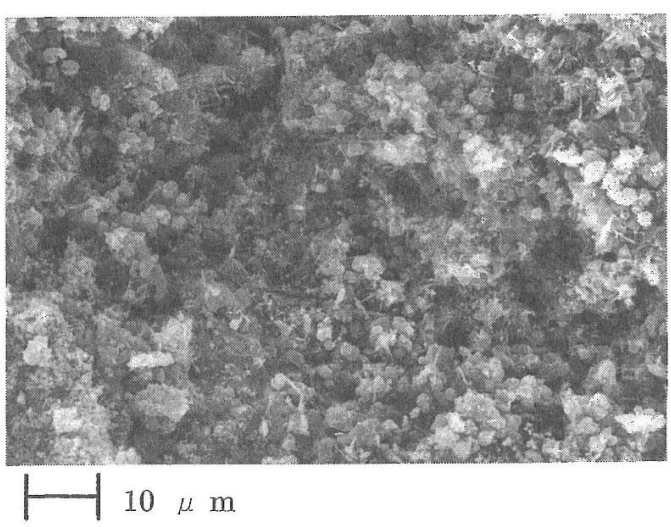

Fig. 9. SEM micrograph showing the fracture surface of the briquette made from pretreated coal ash with $\mathrm{HCl}$ solution and additive of waste silica.
きく, ケイ石廃泥添加量 0.25 では曲げ強度 $19.5 \mathrm{MPa}$, かさ密度 $1.6 \mathrm{Mg} / \mathrm{m}^{3}$ となった。 Fig. 8 よりケイ石廃泥を 添加した場合, 添加量の増加とともにかさ密度が増加し， 強度も高くなる傾向にあることが分かる。

$\mathrm{HCl}$ 処理した石炭灰を原料とした硬化体では，ケイ 石廃泥の添加によって大きく曲げ強度は向上した。特に， $\mathrm{Ca} / \mathrm{Si}=0.7,1.0$ の硬化体では, 未燃焼カーボンを取 り除いた硬化体よりも，かさ密度は小さく曲げ強度は大 きいという優れた特性を示した。これらの硬化体では, ケイ石廃泥から生成したトバモライト， C-S-H 等のケ イ酸カルシウム水和物と, 骨材として働く未反応石英が 硬化体強度を向上させた原因と考元られる。 $\mathrm{Ca} / \mathrm{Si}$

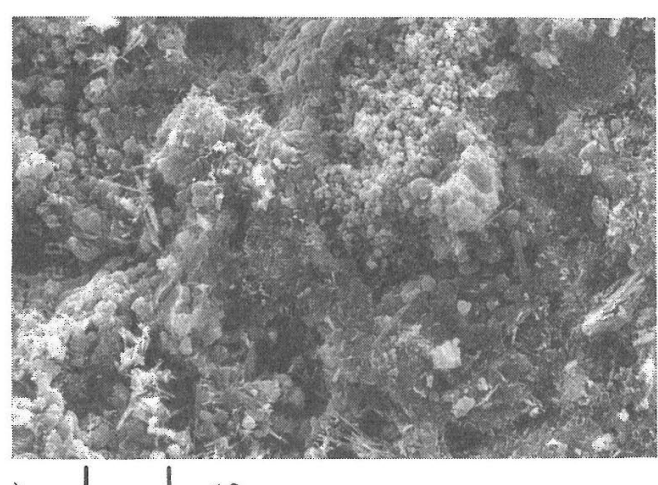

a) $10 \mu \mathrm{m}$

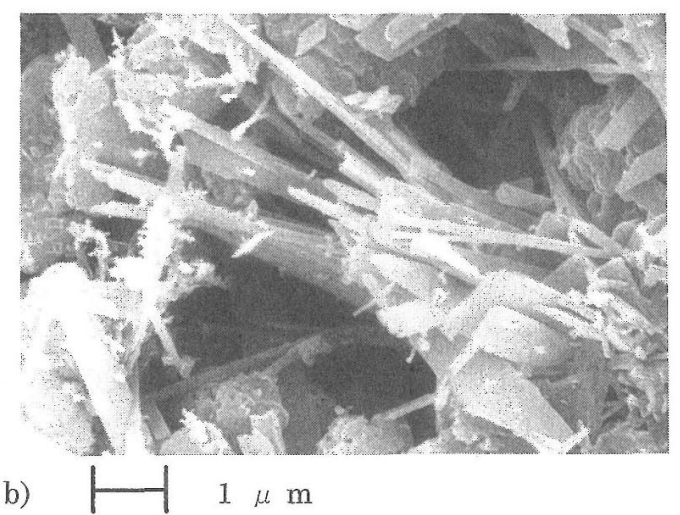

Fig. 10. SEM micrograph showing the fracture surface of the briquette made from pretreated coal ash with $\mathrm{NaOH}$ solution and additive of waste silica. 
$=1.2$ の硬化体でかさ密度が増加したにもかかわらず強 度が低下したのは，未反応石英量が約 $20 \%$ まで減少し， 骨材として機能し難くなったためと考えられる.

Fig. 9 に $\mathrm{HCl}$ で前処理した石炭灰を原料とした硬化 体の破断面の様子を示す. 破断面には多くの針状のトバ モライトの結晶が見られたが，トバモライトの結晶は小 さく, Fig. 4 のケイ石廃泥を添加しない場合と同様に八 イドロガーネットやゲル状の C-S-H の組織中に生成し ていた.

$\mathrm{NaOH}$ 処理した石炭灰を原料とする硬化体では, $\mathrm{HCl}$ 処理した硬化体と同様にかさ密度は低下したが, 硬化体 強度も低下した。吸水率，気孔率の值から判断すると $\mathrm{HCl}$ で前処理した硬化体と同等かむしろ緻密な硬化体 が作製されていた. Fig. 10 に $\mathrm{NaOH} て ゙$ 前処理した石炭 灰を原料とする硬化体の破断面の SEM 写真を示す.

Fig. 9 と比較すると, 針状あるいは柱状のトバモライト の結晶が発達し, 低倍率でも柱状のケイ酸カルシウムが 集合した組織が観察された. 発達した柱状の結晶の周辺 では，大きな空孔が存在した． $\mathrm{HCl}$ 処理した石炭灰を 用いた硬化体に比べて曲げ強度が低下した原因として, 未反応石英量が減少したことに加え, ケイ石廃泥を添加 しない場合と同様に大きな空孔を有する組織となったた めと考えられる.

\section{4 結 言}

未燃焼カーボンを含有する石炭灰を $\mathrm{HCl}$ 溶液あるい は $\mathrm{NaOH}$ 溶液で前処理し反応性を向上させた石炭灰を 原料として，水熱処理により硬化体を作製した. $\mathrm{HCl}$ 処理, $\mathrm{NaOH}$ 処理ともに石炭灰の反応性は向上し, 八 イドロガーネットは, 処理時間 1 時間で生成した. 水熱 処理初期のハイドロガーネットの生成とともに硬化体の 緻密化が進行し, 強度は急激に上昇した. 30 時間以上 の水熱処理により C-S-H，トバモライトが生成した.
$\mathrm{HCl}$ 処理した石炭灰を用いた場合，水熱処理 72 時間後 の硬化体の特性值は, かさ密度 $1.32 \mathrm{Mg} / \mathrm{m}^{3}$, 曲げ強度 $12.0 \mathrm{MPa}$ であった. $\mathrm{NaOH}$ 処理した石炭灰を用いた場 合, 72 時間後の硬化体の特性值は, かさ密度 $1.32 \mathrm{Mg}$ $/ \mathrm{m}^{3}$, 曲げ強度 $9.8 \mathrm{MPa}$ であった. 硬化体の強度を向 上させるためケイ石廃泥を添加した，石炭灰の前処理に よって間接的にケイ石廃泥の反応性も向上した.これは, 前処理により石炭灰の反応性が向上し, 硬化体に多くの 空隙が発生し, 溶媒の侵入が容易となるためと考えられ る. かさ密度-曲げ強度の值にもとづき石炭灰の最適処 理条件を考えると, $\mathrm{HCl}$ 前処理, $\mathrm{Ca} / \mathrm{Si}=1.0$ としケイ 石廃泥を添加した場合であり, この時かさ密度 $1.42 \mathrm{Mg}$ $/ \mathrm{m}^{3}$, 曲げ強度 $18.7 \mathrm{MPa}$ を有する硬化体が得られた。 これは未燃焼カーボンを取り除いた石炭灰を用いて作製 した硬化体の值より優れていた。

最後に, この研究は徳島大学地域共同センターの共同 研究プロジェクトの一つとして行われた. また精力的に 実験に協力された, 当時徳島大学工学部学生・橋本伊智 郎君に感謝いたします。

（平成 7 年 4 月 19 日 日本材料学会高圧力部門委員会第 7 回公開シンポ ジウムにて講演)

\section{参 考 文 献}

1) 芦田利文, 越 一之, 中林一朗, 林 晋一, 材料, 44, 170 (1995).

2 ) 恒松修二, 井上憲弘, 原 尚道, 石膏と石灰, 211, 12 (1988).

3 ) 恒松修二, 井上憲弘, 原 尚道, 石膏と石灰, 212,11 (1988).

4 ) 平島 康, 郡 寿也, 鈴江俊二, 中林一朗, 材料, 37, 1228 (1988). 